\title{
Implications of automation in engineer-to-order production: a case study
}

\author{
Børge Sjøbakk • Maria Kollberg Thomassen • \\ Erlend Alfnes
}

Received: 11 February 2014/ Accepted: 9 April 2014/Published online: 22 May 2014

(C) Shanghai University and Springer-Verlag Berlin Heidelberg 2014

\begin{abstract}
In order to retain a certain level of production in Norway, suppliers to the Norwegian maritime industry need to lower their production costs. Automation is generally an effective way of achieving this in standardized high-volume, low variety production. However, manufacturing companies in the Norwegian maritime industry typically supply capital-intensive, advanced and customized products in low volumes. In this engineer-to-order production situation, manual labor is traditionally preferred over automation. Nonetheless, such companies increasingly automate parts of their production. This paper presents a case of a supplier that has chosen to automate its welding operations, the implications and determinants of this decision.
\end{abstract}

Keywords Engineer-to-order (ETO) - Automation . Maritime industry $\cdot$ Case study

\section{Introduction}

Norway, and especially the Mid-Norway region, has a strong and important tradition as an industrial actor. In recent years, small and medium sized companies in the region have increased their focus on export towards the global market [1]. Particularly, suppliers in the maritime

B. Sjøbakk $(\bowtie) \cdot$ M. K. Thomassen

Industrial Management, SINTEF Technology and Society,

Trondheim, Norway

e-mail: borge.sjobakk@sintef.no

E. Alfnes

Department of Production and Quality Engineering, Norwegian University of Science and Technology, Trondheim, Norway industry are experiencing a shift in their main markets to the East [2]. These companies typically supply capitalintensive, advanced and customized products in low volumes in fulfillment of customer orders. The production situation may be characterized as engineer-to-order (ETO). ETO has many competitive advantages, but is also costly due to the highly complex and labor intensive activities carried out in this type of production. Intensification of the global competition, with an ever-increasing cost pressure, forces many western manufacturing companies to move operations to low-cost countries. In order to retain a certain level of production in Norway, Norwegian suppliers to the maritime industry need to lower their production costs without lowering the quality of their products.

Automation is generally considered to be an effective way of achieving cost reductions in terms of reduced labor costs, decreased production cycle times and increased quality [3]. Most of the traditional literature on automation concentrates on high-volume, low-variety production, claiming that automation is highly suitable for standardized processes and products more effectively. In fact, typical characteristics of the ETO production situation, like technical complexity, customization, short product life cycles and variable demand are examples of situations in which manual labor traditionally has been preferred over automation [3]. According to the Norwegian Board of Technology technological developments in, e.g., robot technology and 3D printing are believed to shift this paradigm. In a recent report [4] the board points out that next generation industrial robots are more precise, smaller, more flexible, easier to program and safer to use in cooperation with humans-enabling them to handle greater technical complexity and deliver higher quality. This is backed up by success stories from the Norwegian companies Ekornes, Kværneland, GKN Aerospace Norway and Kleven that 
have all managed to retain production in Norway by investing in advanced production technology.

Even though some companies have succeeded in automating parts of their production, Norway's share of industrial robots per worker is still lower than that for many other countries [4]. A starting point of this research is that this is at least partly due to a lack of tools and methodologies supporting companies in making sound automation decisions [5]. There are many arguments why companies should adopt a systematic approach to automation decisions. The risk for unsuccessful investments in advanced production equipment is high and companies tend to make large investments in equipment that only give limited payoff [6]. Too much capacity, excess functionality and equipment that does not fulfill its potential are typical problems of investments in advanced production equipment [7]. Several challenges of automation projects are related to assessing different solutions and selecting an appropriate solution, developing a requirement specification and making reliable investment calculations [8]. Previous studies have shown that the implementation of advanced production equipment has not been as successful or straightforward as expected and part of the explanation to this is related to the use of insufficient foundation for making investment decisions [9]. Companies with major experience from automation have adopted comprehensive acquisition processes [10] and those that make major implementation efforts can be expected to achieve higher performance benefits from advanced equipment investments [9].

Companies can choose from a large variety of techniques and methods for evaluating and justifying investments in advanced production technology $[11,12]$. There is however a need to develop new approaches because many evaluation models have been criticized for being inaccurate, time-consuming, too simple and too specific [11]. In addition, traditional approaches to investment in advanced equipment do not consider the value of product mix flexibility [13].

This paper presents the case of a Norwegian supplier to the maritime industry that has decided to automate parts of its welding operations, and what are the implications and determinants of such decisions. The purpose of the research is to better understand the impact of such decisions, and the paper is a first step towards developing a methodology for systematic automation decisions in the ETO production situation.

The rest of this paper is organized as follows. First, the research method is described. Thereafter, the theoretical background of this research is provided. It includes a brief presentation of the ETO production situation, automation strategy, levels and different types of automation. This is followed by a presentation of the case company, its decision to automate parts of its production and the impact of this decision. A brief discussion sheds light on how the impact coincides with the characteristics of the ETO production situation and theory on automation. Finally, conclusions are presented.

\section{Research method}

This research is based upon a qualitative approach, utilizing a combination of case study [14, 15] and action research $[16,17]$. Case studies are typically recommended when the research is of an exploratory nature, and when the researchers investigate contemporary events while being unable to manipulate behavioral events [14]. For this particular activity where immediate implications of automation decisions are explored, the researchers are unable to manipulate behavior. In line with Yin [14], a case study of the supplier has therefore been carried out. Semi-structured, focused interviews have been carried out with company representatives having supply chain management, production planning and control, and automation expertise. As for the overall long-term project, the researchers will actively share insights to the company by carrying out action research [17], i.e., doing collaborative problem solving while having a research interest in mind [16].

Like any other research methods, both case studies and action research have some shortcomings, especially regarding generalizability and the reliability of the results. The authors acknowledge that the idiosyncratic context of the researchers and the problem holder impede the possibility to fully generalize and replicate the research and its results. To achieve as high quality as possible, the case company and its decision to automate are thoroughly described in Section 4.

\section{Theoretical background}

In this section, the theoretical background of this research is provided. This includes a presentation of the ETO production situation, automation strategy, different levels and types of automation. The theoretical background serves the purpose of increasing the reader's understanding of the case company's context and its decision to automate.

\subsection{ETO production situation}

Many classifications have been made with the purpose to distinguish between different production situations [18]. Most of the operations management and production literatures would classify companies within one of four production situations: make-to-stock (MTS), assemble-to- 


\begin{tabular}{ccccc}
\hline $\begin{array}{l}\text { Product } \\
\text { delivery } \\
\text { strategy }\end{array}$ & Design & $\begin{array}{c}\text { Fabrication } \\
\text { and pro- } \\
\text { curement }\end{array}$ & $\begin{array}{c}\text { Final as- } \\
\text { sembly }\end{array}$ & Shipment \\
\hline $\begin{array}{r}\text { MTS } \\
\text { ATO }\end{array}$ & $-\cdots \cdots \cdots$ & CODP $\longrightarrow$ \\
MTO & $-\cdots \cdots+\cdots$ & CODP & $\stackrel{\text { CODP }}{\longrightarrow}$ \\
ETO & CODP & $\longrightarrow$ & \\
\hline
\end{tabular}

Fig. 1 Production situations and the CODP [21]

Table 1 Typical ETO characteristics

\begin{tabular}{|c|c|c|}
\hline $\begin{array}{l}\text { Unit of } \\
\text { analysis }\end{array}$ & Typical characteristics & References \\
\hline Products & $\begin{array}{l}\text { Complex } \\
\text { Deep product structure (many } \\
\text { components) } \\
\text { Low volume on product level, higher on } \\
\text { sub-assembly and component level } \\
\text { Mix of standardized and customized } \\
\text { components } \\
\text { High degree of customization_- "one of } \\
\text { a kind products" } \\
\text { High product variety } \\
\text { Long lead times } \\
\text { Frequent changes }\end{array}$ & $\begin{array}{c}{[18,23,27,} \\
29,30]\end{array}$ \\
\hline Processes & $\begin{array}{l}\text { Business processes divided into three } \\
\text { stages: marketing, tendering and } \\
\text { contract execution } \\
\text { Temporariness, uniqueness and multi- } \\
\text { functionality } \\
\text { Focus on flexibility } \\
\text { General purpose equipment } \\
\text { Non-routine work processes } \\
\text { Job shops/projects }\end{array}$ & {$[27,29-31]$} \\
\hline Markets & $\begin{array}{l}\text { Uncertainty in demand and product mix } \\
\text { External flexibility needed in handling } \\
\text { the uncertainty }\end{array}$ & {$[18,32]$} \\
\hline $\begin{array}{l}\text { Uncertainty } \\
\text { and risk }\end{array}$ & $\begin{array}{l}\text { Three types of risk: technical risk, time } \\
\text { risk and financial risk } \\
\text { Uncertainty in product specifications, } \\
\text { process specifications and product mix } \\
\text { and volume }\end{array}$ & {$[18,33]$} \\
\hline Challenges & $\begin{array}{l}\text { Long lead times } \\
\text { Uncertain delivery dates } \\
\text { Handling change orders } \\
\text { Production planning and control } \\
\text { Product quality } \\
\text { Conflicts in manufacturing/marketing } \\
\text { schedules } \\
\text { Material waste }\end{array}$ & {$[28,34-39]$} \\
\hline
\end{tabular}

order (ATO), make-to-order (MTO) and ETO [19]. These production situations relate to different positions of the customer order decoupling point (CODP) [20], i.e., the point in time where production goes from being forecastdriven to order-driven [21]. Figure 1 illustrates how different positions of the CODP give rise to different production situations. In the figure, dashed and solid lines refer to forecast- and order-driven activities, respectively.

In accordance with Fig. 1, ETO can be defined as a production situation in which products are manufactured to meet a specific customer's needs by unique engineering or significant customization [19]. As such, an ETO company knows little about what to order or manufacture until after the receipt of a customer order and subsequent engineering [18].

Several authors argue that the above mentioned production situations are broad and imprecise divisions, which leads to a considerable diversity of companies included in each category [19], and to manufacturing organizations not falling solely within one class [22]. As a response to this, researchers have developed more specific taxonomies for non-MTS [19] and ETO [23-25]. According to Hicks et al. [23], ETO companies vary in terms of degree of vertical integration in various levels of the product structure. Further, customer requirements may be translated into specifications at product, subassembly and/or component level [26]. As such, the diversity of components, sub-assemblies and products in ETO is high [27]. Some are required only in low volumes whereas others are needed in higher volumes; some are standardized whereas others are customized; some are technologically advanced whereas others are not. This means that parts of an ETO product may be produced by using logic from other production situations. For some standard components needed in high volumes an MTS logic may be applied, whereas for other highly customized components the ETO path outlined in the bottom of Fig. 1 has to be followed.

The context around an ETO company is characterized by a high degree of uncertainty, with high fluctuations in, for instance, sales volume and product mix [18]. Further, short term dynamics in form of change orders is common for ETO companies, and the capability to respond to these is often a prerequisite for success [28]. The typical characteristics of the ETO product situation are summarized in Table 1.

\subsection{Flexible manufacturing by means of industrial robots}

The capability to automatically manufacture highly customized products in small lot sizes depends mainly on setup time, the flexibility of the tools, the time required to change tools, calibration of positioning devises, sensors and their programming [40]. In this respect, industrial robot-based automation is argued to represent the best solution for both productivity and flexibility [41]. Industrial robots have been used in manufacturing since their 
introduction in the early 1970s [42]. They were initially applied to jobs that were hot, heavy, and hazardous, such as die-casting, forging, and spot welding, but are now used in a wide range of industrial applications, such as welding, spray painting, assembly, palletizing and materials handling and dispensing operations [43]. For such production tasks, which typically are standardized and repetitive, industrial robots can perform their tasks cost effectively and accurately over longer periods of time [44]. However, in order to cope with today's competitive markets, industrial robots need to become even more intelligent, collaborative and multipurpose, with a more effortless adaptation to the processes they are to perform, to efficiently produce one-offs or limited series [44].

Robots' wide range of applications stems from their versatility. This versatility derives from the generality of the robots' physical structure and control, which can only be exploited if the robot can be programmed easily [45]. This, however, is rarely the case. The programming of an industrial robot system for a specific application is generally difficult, time-consuming and expensive [41]. In many cases, the cost of programming itself accounts for a significant portion of the cost of the entire industrial robot system, as production-grade robot systems can require days or weeks of effort from highly trained robot programmers, depending on the systems' type of application [46]. There are some studies report about programming times exceeding 300 times the automated process' cycle times [41]. In the case of product customization, with frequent product changeover, maintaining and editing robot programs is a major issue [46], and the complexity of programming remains one of the key obstacles preventing the use of industrial robots in many companies [41]. With computer technology becoming more powerful and graphical in nature, many attempts for making industrial robots easier to program are now made [46]. One such initiative is CAD based programming, where the user inputs CAD data and a software (semi-) automatically generates robot programs which are uploaded to the robot when necessary [46]. Such offline programming offers advantages in the form of not requiring access to the robot during work preparation, possibility of modifying parts of the program without altering the entire trajectory of the robot, increased work safety and the possibility to simulate and optimize the robot's operations prior to the actual production phase [41, 47]. Larkin et al. [48] report of CAD based programming being implemented for welding of ship panels, but it is still a key unresolved issue for more complex products and operations $[44,49]$.

Despite its many advantages, offline robot programming has a key drawback that needs to be resolved. When a CAD based robot program is executed on the robot, errors are usually generated due to deviations between the $3 \mathrm{D}$ model and the actual robot cell, as well as due to imperfections of the mechanical robot structure [40]. Position and trajectory accuracy are identified as the main problems of industrial robots [44]. Therefore, offline generated robot paths still need much adjustment in order to obtain a usable robot path [49]. Methods to improve robot positioning accuracy are classified as either model based or sensor based [50]. In the model based method, the robot's position is altered according to a prediction of the robot's behavior and deformation under the anticipated workload, whereas the sensor based method relies on a measured deviation between the intended and the actual robot position [40]. The sensor based method offers higher position accuracy than the model based method, but it is difficult and costly to implement on existing robot manipulators [50]. There are some reports of laboratory demonstrations showing how sensors can be combined with complex analysis to give important information about the state of a manufacturing process [51]. However, in one-off or limited series production, a new set of quality characteristics is defined whenever a product is customized [52], and doing things right the first time becomes even more important than before. Thus, knowing the state of the process is insufficient, and there is a need for adaptive control, i.e., automatic adjustment of process parameters [53]. Adaptive control is not yet commonly integrated into today's industrial robots. Overcoming the obstacles associated with sensor based compensation and correction methods is an important step towards zero-defect manufacturing.

\subsection{Automation strategy, levels and types of automation}

Automation is the substitution of machine work for human physical and mental work [54]. It has traditionally been viewed as mechanization of production processes, simple substitution of physical human labor by machines. This view has been changed with the development of computer technology, and today automation is often related to a combination of both mechanization (i.e., automation of physical tasks) and computerization (i.e., automation of control and information handling) [55]. Automation may also refer to technology by which a process or procedure is performed without human assistance [3] or specific devices or systems that accomplish a function that was previously, or conceivably could be, carried out by a human operator [56].

Winroth et al. [57] identify two different perspectives on automation strategy. In the first perspective, the overall manufacturing strategy is equal to an automation strategy, i.e., the strategy is automation [58]. In the second perspective, automation is treated as one of several decisions in a manufacturing strategy-typically within the process 
Table 2 Reference scale of levels of automation [62]

\begin{tabular}{|c|c|}
\hline Level of automation & Description \\
\hline Totally manual & $\begin{array}{l}\text { Totally manual work, no tools are used, only } \\
\text { the users own muscle power }\end{array}$ \\
\hline Static hand tool & $\begin{array}{l}\text { Manual work with support of a static tool, e.g., } \\
\text { screwdriver }\end{array}$ \\
\hline Flexible hand tool & $\begin{array}{l}\text { Manual work with the support of a flexible } \\
\text { tool, e.g., adjustable spanner }\end{array}$ \\
\hline $\begin{array}{l}\text { Automated hand } \\
\text { tool }\end{array}$ & $\begin{array}{l}\text { Manual work with the support of an automated } \\
\text { tool, e.g., hydraulic bolt driver }\end{array}$ \\
\hline $\begin{array}{l}\text { Static machine/ } \\
\text { workstation }\end{array}$ & $\begin{array}{l}\text { Automatic work by a machine that is designed } \\
\text { for a specific task, e.g., lathe }\end{array}$ \\
\hline $\begin{array}{l}\text { Flexible machine/ } \\
\text { workstation }\end{array}$ & $\begin{array}{l}\text { Automatic work by a machine that can be } \\
\text { reconfigured for different tasks, e.g., CNC } \\
\text { machine }\end{array}$ \\
\hline Totally automatic & $\begin{array}{l}\text { Totally automatic work (The machine solves } \\
\text { all deviations or problems that occur by } \\
\text { itself, e.g., autonomous systems.) }\end{array}$ \\
\hline
\end{tabular}

technology decision category [59]. Here, companies must consider business, operational, social and political and regulatory issues when making choices about automation. These priorities will vary with the position a company wants to occupy with respect to product volume and variety [59], i.e., with different production situations.

Distinguishing between different levels of automation is important in order to ensure alignment between automation choices, the manufacturing strategy and the overall business objectives [5], which in turn affects the performance of manufacturing firms [58]. The level of automation may be defined as the degree to which automation can be used in a production process to replace human labor by machines [60, 61]. Various levels of automation are discussed in Refs. [3, 60-62]. On an overall level, Groover [3] distinguishes between semi-automated and fully automated production systems, where semi-automated machines imply human interaction between cycles whereas fully automated machines are operated with longer work cycles and less human interaction. On a lower level, he defines level of automation as a position in the automation hierarchy, i.e., device, machine, cell/system or enterprise level.

Frohm [62] proposes a more detailed categorization of the level of categorization (see Table 2). Spanning from fully manual to fully automatic, the categorization relates to the allocation of tasks between humans and technology. Frohm [62] claims that it is not relevant to discuss the assessment of automation in terms of the absolutely maximum and minimum levels but to focus on relevant levels of automation. He further suggests that this reference scale can be used to allocate different tasks to either the human or the technical system. For tasks that cannot be allocated to either the human or the technical system, the scale can be used to define the relevant maximum and minimum level of automation for each task.

Automation strategies need to take a wide range of conditions into consideration. These may be related to, e.g., human performance [30, 56, 63], economic conditions [64] and existing equipment $[3,65]$. Consequently, determining the appropriateness of automation in ETO production may depend upon a significant range of factors. Production volume and product variation are often highlighted as important factors for choosing an appropriate level and type of automation [66]. Conventional standard machinery or machining centers are, for example, primarily regarded appropriate for low volume, high variety parts [64] while automation traditionally is regarded as most suitable for higher volumes and less varieties [3, 64].

Examples of additional product and production related characteristics include physical characteristics of parts such as size, weight and geometry [3]; product modularity or common parts that are used in different products [65]; part routing or the routes that parts should follow and ability of the part to be processed using a different route [3, 65]; layout flexibility or the ability of the plant layout to react to disturbances [65]; production rates, operation sequences, setup time and dedication of equipment [3]; and the amount of physical space required [67].

To conclude, the ETO production situation may be characterized by a number of categories. The position a company wants to take with respect to these categories may in turn influence what kind of automation that ensures alignment between the automation strategy, the manufacturing strategy and the overall business goals. In this respect, distinguishing between different levels of automation may be useful. In Section 4, the case company and its decision to automate parts of its production are described.

\section{Case findings}

This research is carried out in collaboration with a Norwegian supplier of high-tech ship equipment. The company, which is located in Mid-Norway, designs, produces and delivers complete systems for the maritime industry worldwide. It is part of Norwegian Center of Expertise (NCE) Maritime, which is a constellation of over 200 leading maritime companies and training, research and finance institutions operating actively within the maritime industry. The company mainly delivers complete systems directly to shipyards, however parts for repairs and upgrades are also supplied to ship-owners in the aftermarket. The systems can be tailored to customers' specific operational requirements, and are customized to the hull in 
which they are to be installed. The production of any system is triggered by a customer order.

The company's in-house expertise in hydraulics, hydrodynamics, electronics, mechanical and electrical engineering and production enables it to offer a completely technological environment including component production, sub-assemblies of modules and main assemblies of systems.

The company has been able to retain production activities in Norway due to the high quality of its products. However, as is the case for many Norwegian suppliers to the maritime industry, it is increasingly becoming exposed to global competition which creates a need to cut costs in production. The company has already decided to automate the welding operations, as closely located companies with similar characteristics (e.g., Kleven, as mentioned in Section 1) have succeeded in cutting costs by doing so. An automation expert has been recruited to help with this process. However, for the company's remaining operations the questions of which processes to automate, and to which degree they should be automated, still remain. The company needs a practical and systematic approach to decide the appropriate automation strategy for its factory. As mentioned in Section 1, this paper is a first step towards such a methodology.

The company has long tradition in automation and technology adoption, especially in high-volume parts production. With the rapid development of new technology for flexible manufacturing and robotics, it now sees a potential in automating processes that traditionally have been considered as less appropriate for automation. Following an evaluation of the company's processes with respect to labor hours, production volumes and available technology, etc., the final decision to automate parts of the company's welding operations was taken by the board of directors. Following the decision, five automation technology vendors were evaluated, whereupon a supplier which delivered similar solutions for other companies within the region was selected. The company has received a welding robot in the first quarter of 2014. This robot could contribute to cost reduction mainly by performing welding operations significantly faster (approximately four times) than human operators are able to today, while consuming less materials in the process due to improved welding techniques. Further, the robot will impact today's welding operations in terms of available processing time, changes in product designs and procedures, and new roles and skills requirements:

\section{(i) Available processing time}

Today, the welding processes depend on operators' availability. Automated welding will increase the available processing time by enabling unmanned overnight welding.
The robot will be able to automatically notify an operator via mobile phone about its status.

\section{(ii) Change in product designs and procedures}

Some of today's products and components have too complex structures for a robot to perform operations on them. These will have to be redesigned in order for them to be automatically welded. Such changes may propagate to other parts of the systems. Further, the increased welding speed and techniques introduced by the welding robot requires new welding routines to be made for all products and components undergoing welding operations.

\section{(iii) New roles and skills requirements}

The roles of today's welders will change significantly with the introduction of a welding robot. From having done all the welding, the operators will now mainly carry out spot welding and prepare products and components for the robot to weld them. Further, the robot creates a need for experienced robot operators that are capable of programming for every unique product and component.

Even though cost reductions in welding may be achieved by investing in automated solutions, the company is aware that it should not necessarily automate all of today's operations. The decision of what to automate is influenced by, but not limited to, material constraints, the efficiency of existing operations, complexity of automation and restricted space:

\section{(i) Material constraints}

For example, varying steel quality may make the automation of certain processes difficult. In some rolling processes, the steel quality vary significantly.

\section{(ii) Efficiency of existing operations}

Some operations are currently too efficient to benefit enough from automating them. For example, welding of the systems' housings has been severely improved over the years, and has similar efficiency as existing automated solutions. If a person can perform an operation as efficient as a robot, the operation should not necessarily be automated.

\section{(iii) Complexity of automation}

Efficient programming is a prerequisite for cutting costs through automation. If every product and component is different, a person is likely to carry out an operation faster than a robot.

\section{(iv) Restricted space}

Automated solutions are often space-requiring. In some cases, this may limit the possibility to automate. 


\section{Discussion}

The decision to invest in a welding robot was taken due to its potential to significantly reduce production costs through reduced cycle times and less material consumption. As such, it is treated as one of several decisions in the company's manufacturing strategy rather than forming the actual strategy of the company [57]. In this situation, the company should ultimately consider business, operational, social and political and regulatory issues when making the choice to automate [59]. It was neither clear nor particularly relevant to discuss whether social, political and/or regulatory issues were taken into account when the decision was made. However, for the business and operational aspects, it may be beneficial to compare the chosen solution with the characteristics of the company's ETO production situation.

The welding robot requires manual spot welding and other preparation between cycles. Using the overall distinction by Groover [3], the solution therefore corresponds to the semi-automated production system category. In order to cater to ETO characteristics, such as high degree of customization, high product variety, frequent product changes and flexibility focus (see Table 1), the chosen solution is extremely flexible given a situation of having the necessary skills is in place, with no material constraints and manageable programming of product automation programs. Such flexible machines/workstations refer to the sixth level of automation, as defined by Frohm [62]. In comparison, the traditional way of welding corresponds to the second level of automation, i.e., manual work with support of a static tool. This allocation of tasks between humans and technology seems beneficial given the business and operation aspects of ETO. It is though worth mentioning that in the purest form of ETO, with every part being unique, the company claims that manual labor is more efficient than automation. However, as the diversity of components, subassemblies and products in ETO usually is high, with both high and low volumes, standardization and customization, simplicity and complexity [27], in general automation is likely to be an efficient means to reduce costs, at least in parts of an ETO company's operations.

\section{Conclusions}

In this paper, the case of a Norwegian supplier to the maritime industry, its decision to automate parts of its welding operations and the implications of this decision are described. It is found that the investment in a new welding robot influences today's welding operations in terms of increased available processing time, changes in product designs and procedures, new roles and skills requirements.
The decision to further automate other processes is found to be influenced by, but not limited to, material constraints, the efficiency of existing operations, complexity of automation and restricted space. For the manufacturing of products and components with suitable characteristics, automation is believed to be an effective means of cost reductions.

A need for tools and methods guiding companies in making automation decisions has been identified in the literature. This case study has helped to better understand the impact of automation decisions, and the paper is a first step towards developing a methodology for systematic automation decisions in the ETO production situation. Such methodology would help managers to make sound automation decisions that are aligned with the company's competitive priorities and functional strategies. This is likely to contribute to retaining manufacturing operations in Norway. Further research should include investigating the implications of similar automation decisions in other empirical settings, including other processes, automation technologies and contextual conditions.

Acknowledgements This work has been conducted within the context of the projects Effective Production of Advanced Maritime Equipment (EFFEKT), Sustainable multi-variant manufacturing in semi-process industry (MIX) and the SFI Norman (Norwegian Manufacturing Future) program supported by the Research Council of Norway. The authors would like to thank the participants of the projects for providing valuable empirical data.

\section{References}

1. NHO (2007) Trøndelag i verden næringslivets hovedorganisasjon trøndelag. In: The 3rd international workshop of advanced manufacturing and automation,Trondheim, Norway, 27 Nov 2013

2. Maritim21 (2010) En bærekraftig maritim forsknings- og innovasjonssatsing: kunnskapsnav og infrastruktur. http://www.mar itim21.no/wp-content/uploads/2009/12/M21-Rapport-Kunnskaps nav-og-infrastruktur-v1.pdf

3. Groover MP (2008) Automation, production systems, and computer-integrated manufacturing. Prentice Hall Press, New Jersey

4. Teknologirådet (2013) Made in Norway? Hvordan roboter, 3Dprintere og digitalisering gir nye muligheter for norsk industri. http://www.steampdf.com/view/made-in-norway-hvordan-roboter3d-printere-og-digitalisering-gir-nye-muligheter-for-norsk-indus tri-26777572.html

5. Lindström V, Winroth M (2010) Aligning manufacturing strategy and levels of automation: a case study. J Eng Technol Manag 27:148-159

6. Chung CA (1996) Human issues influencing the successful implementation of advanced manufacturing technology. J Eng Technol Manag 13:283-299

7. Mehrabi MG, Ulsoy AG, Koren Y et al (2002) Trends and perspectives in flexible and reconfigurable manufacturing systems. J Intell Manuf 13:135-146

8. Granlund A, Jackson M (2013) Managing automation development projects: a comparison of industrial needs and existing theoretical support. In: Azevedo A (ed) Advances in sustainable 
and competitive manufacturing systems. Springer, Berlin, pp 761-774

9. Small MH (2007) Planning, justifying and installing advanced manufacturing technology: a managerial framework. J Manuf Technol Manag 18:513-537

10. Friedler N, Salonen A, Johansson C (2013) The automation equipment acquisition process-experienced users' perspective. In: the 22nd International Conference on Production Research, Iguazu

11. Ordoobadi SM, Mulvaney NJ (2001) Development of a justification tool for advanced manufacturing technologies: system-wide benefits value analysis. J Manuf Technol Manag 18:157-184

12. Banakar Z, Tahriri F (2010) Justification and classification of issues for the selection and implementation of advanced manufacturing technologies. World Acad Sci Eng Technol 65:341-349

13. Fernandes R, Gouveia JB, Pinho C (2012) Product mix strategy and manufacturing flexibility. J Manuf Syst 31:301-311

14. Yin RK (2009) Case study research: design and methods. Sage Publications Inc, Thousand Oaks, CA

15. Eisenhardt KM (1989) Building theories from case study research. Acad Manag Rev 14(4):532-550

16. Greenwood DJ, Levin M (2007) Introduction to action research: social research for social change. Sage, Thousand Oaks

17. Gummesson E (2000) Qualitative methods in management research. Sage Publications, Thousand Oaks

18. Bertrand J, Muntslag D (1993) Production control in engineer-toorder firms. Int J Prod Econ 30:3-22

19. Amaro G, Hendry L, Kingsman B (1999) Competitive advantage, customisation and a new taxonomy for non make-to-stock companies. Int J Oper Prod Manag 19:349-371

20. Wortmann J (1992) Production management systems for one-ofa-kind products. Comput Ind 19:79-88

21. Olhager J (2003) Strategic positioning of the order penetration point. Int J Prod Econ 85:319-329

22. Porter K, Little D, Peck M et al (1999) Manufacturing classifications: relationships with production control systems. Integr Manuf Syst 10:189-199

23. Hicks C, McGovern T, Earl CF (2001) A typology of UK engineer-to-order companies. Int J Logist 4:43-56

24. Wacker JG, Miller M (2000) Configure-to-order planning bills of material: simplifying a complex product structure for manufacturing planning and control. Prod Inven Manag J 41:21

25. Wikner J, Rudberg M (2005) Integrating production and engineering perspectives on the customer order decoupling point. Int $\mathbf{J}$ Oper Prod Manag 25:623-641

26. McGovern T, Hicks C, Earl CF (1999) Modelling supply chain management processes in engineer-to-order companies. Int $\mathbf{J}$ Logist Res Appl 2:147-159

27. Hicks C, McGovern T, Earl C (2000) Supply chain management: a strategic issue in engineer to order manufacturing. Int $\mathrm{J}$ Prod Econ 65:179-190

28. Little D, Rollins R, Peck M et al (2000) Integrated planning and scheduling in the engineer-to-order sector. Int $\mathrm{J}$ Comput Int Manuf 13:545-554

29. Stavrulaki E, Davis M (2010) Aligning products with supply chain processes and strategy. Int J Logist Manag 21:127-151

30. Rahim ARA, Baksh MSN (2003) The need for a new product development framework for engineer-to-order products. Eur $\mathbf{J}$ Innov Manag 6:182-196

31. Caron F, Fiore A (1995) "Engineer to order" companies: how to integrate manufacturing and innovative processes. Int $\mathrm{J}$ Proj Manag 13:313-319

32. Gosling J, Naim MM (2009) Engineer-to-order supply chain management: a literature review and research agenda. Int J Prod Econ 122:741-754
33. Muntslag DR (1994) Profit and risk evaluation in customer driven engineering and manufacturing. Int J Prod Econ 36:97-107

34. Hicks C, Braiden P (2000) Computer-aided production management issues in the engineer-to-order production of complex capital goods explored using a simulation approach. Int J Prod Res 38:4783-4810

35. Krajewski L, Wei JC, Tang LL (2005) Responding to schedule changes in build-to-order supply chains. J Oper Manag 23:452-469

36. Pandit A, Zhu Y (2007) An ontology-based approach to support decision-making for the design of ETO (engineer-to-order) products. Automat Constr 16:759-770

37. Elfving JA, Tommelein ID, Ballard G (2005) Consequences of competitive bidding in project-based production. J Purch Supply Manag 11:173-181

38. Danese P, Romano P (2004) Improving inter-functional coordination to face high product variety and frequent modifications. Int J Oper Prod Manag 24:863-885

39. Terwiesch C, Loch CH (1999) Managing the process of engineering change orders: the case of the climate control system in automobile development. J Prod Innov Manag 16:160-172

40. Minhas S, Lehmann C, Städter J et al (2011) Reconfigurable strategies for manufacturing setups to confront mass customization challenges. In: the 21st International Conference on Production Research (ICPR 21), Stuttgart, Germany

41. Pan Z, Polden J, Larkin N et al (2012) Recent progress on programming methods for industrial robots. Robot Comput Integr Manuf 28:87-94

42. Johansson R, Robertsson A, Nilsson K et al (2004) Sensor integration in task-level programming and industrial robotic task execution control. Ind Robot Int J 31:284-296

43. Forge S, Blackman C (2010) A helping hand for Europe: the competitive outlook for the EU robotics industry. EUR-Scientific and Technical Research Reports, Publications Office of the European Union

44. Essers M, Vaneker T (2013) Developing concepts for improved efficiency of robot work preparation. Procedia CIRP 7:515-520

45. Lozano-Perez T (1983) Robot programming. Proceedings of the IEEE 71(7):821-841

46. Rossano GF, Martinez C, Hedelind M et al (2013) Easy robot programming concepts: an industrial perspective. In: 2013 IEEE International Conference on Automation Science and Engineering (CASE), pp 1119-1126

47. Neto P, Mendes N (2013) Direct off-line robot programming via a common CAD package. Robot Autonom Syst 61(8):896-910

48. Larkin NP, Milojevic A, Pan Z et al (2011) Offline programming for short batch robotic welding. In: The 16th International Conference on the Joining of Materials, Denmark

49. Chen H, Sheng W (2011) Transformative CAD based industrial robot program generation. Robot Comput Integr Manuf 27:942-948

50. Wang J, Zhang H, Fuhlbrigge T (2009) Improving machining accuracy with robot deformation compensation. In: IEEE/RSJ International Conference on Intelligent Robots and Systems, pp 3826-3831

51. Tan KK, Huang S, Zhang Y et al (2009) Distributed fault detection in industrial system based on sensor wireless network. Comput Stand Interfaces 31:573-578

52. Da Silveira G, Borenstein D, Fogliatto FS (2001) Mass customization: literature review and research directions. Int J Prod Econ 72:1-13

53. Liana SY, Hecker RL, Landers RG (2004) Machining process monitoring and control: the state-of-the-art. J Manuf Sci Eng 126:297-310

54. Blackstone JH, Cox JF (eds) (2010) APICS Dictionary. American Production \& Inventory Control Society, Incorporated

55. Frohm J, Lindström V, Bellgran M (1998) A model for parallel levels of automation within manufacturing. In: the 18th International Conference on Production Research 
56. Parasuraman R, Sheridan TB, Wickens CD (2000) A model for types and levels of human interaction with automation. IEEE Trans Syst Man Cybern A 30:286-297

57. Winroth M, Safsten K, Stahre J (2007) Automation strategies: existing theory or ad hoc decisions? Int J Manuf Technol Manag 11:98-114

58. Säfsten K, Winroth M, Stahre J (2007) The content and process of automation strategies. Int J Prod Econ 110:25-38

59. Beckman SL, Rosenfield DB (2008) Operations strategy, competing in the 21st Century. McGraw-Hill, New York

60. Wickens CD, Mavor AS, Parasuraman R (1998) The future of air traffic control: human operators and automation. National Academies Press, Washington DC

61. Endsley MR (1999) Level of automation effects on performance, situation awareness and workload in a dynamic control task. Ergonomics 42:462-492
62. Frohm J (2008) Levels of automation in production systems. Chalmers University of Technology, Göteborg

63. Parasuraman R, Riley V (1997) Humans and automation: use, misuse, disuse, abuse. J Human Factors Ergon Soc 39:230-253

64. Kalpakjian S, Schmidt SR (2010) Manufacturing, engineering and technology SI. Prentice Hall, Singapore

65. Wadhwa RS (2012) Flexibility in manufacturing automation: a living lab case study of Norwegian metalcasting SMEs. J Manuf Syst 31(4):444-454

66. Bellgran M, Säfsten K (2010) Production development: design and operation of production systems. Springer, Berlin

67. Sarkis J (1997) Evaluating flexible manufacturing systems alternatives using data envelopment analysis. Eng Econ 43:25-47 